\title{
Urinary Incontinence in Pregnant Multigravida from Second Trimester up to the Delivery
}

\author{
Sadia Sharif, ${ }^{1}$ Muhammad Junaid Ijaz Gondal, ${ }^{2}$ Salman Malik Kamboh, ${ }^{3}$ Muhammad Adeel, ${ }^{4}$ Mustafa \\ Qamar, ${ }^{5}$ Asad Chaudhry, ${ }^{6}$ Ramsha Nadeem ${ }^{7}$
}

\begin{abstract}
Structural and physical changes take place in pregnancy such as altered function of urinary tract. The mechanism lying behind low urinary tract function can be described in terms of effects of hormones, compressive dysfunction of uterus and structural changes in pelvic support function. The prevalence of urinary incontinence in developed countries is $27.6 \%$ and in developing countries $28.7 \%$. Urinary incontinence is a functional pelvic floor disorder which affects the wellbeing of all age's women. Urinary incontinence frequency is increased by pregnancy but the cause of this incontinence is still unknown. The prevalence of incontinence differs greatly.
\end{abstract}

Objective: To know the frequency of urinary in-

\footnotetext{
${ }^{1}$ Dept of Physiotherapy, Mayo Hospital, Lahore

${ }^{2}$ Physiotherapist, Dept of Physiotherapy, Mayo Hospital, Lahore

${ }^{3}$ Physiotherapist, Ch. Parvaiz Elahi Institute of Cardiology, Multan

${ }^{4}$ Dept of Physiotherapy, Mayo Hospital, Lahore

${ }^{5}$ Assistant Professor, University of Sargodha

${ }^{6}$ Assistant Professor, Imperial College of Business Studies, Lahore

${ }^{7}$ Physiotherapist, Dept of Physiotherapy, Mayo Hospital, Lahore
}

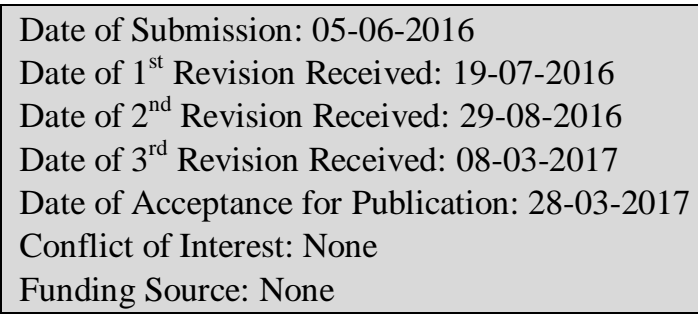

\section{Contribution}

All Authors have contributed in Study Design, Data Collection, Data Analysis, Data Interpretation, Manuscript Writing and Approval. continence among pregnant multigravida from second trimester up to delivery.

Methods: The study design used was a cross-sectional survey. The place of study was Lady Aitchson Hospital Lahore Pakistan and Lady Willington Hospital Lahore Pakistan. It was completed within six months after the approval of synopsis from September 2015 to February 2016. The sample of this study was 706. Mean age of the multigravida belonging to the lower socioeconomic status was 25-28 years of age. Women's continence and pelvic health center urinary incontinence questionnaire was used in this study.

Results: Multigravida included in this study showed $51.1 \%$ of urinary incontinence and $48.8 \%$ with no urinary incontinence. The level of the beginning of urinary incontinence was more in second trimester.

Conclusion: Urinary incontinence is more prevalent in multiparous especially in second trimester of pregnancy.

Key words: Urinary incontinence, multigravida, second trimester, third trimester.

\section{Introduction}

Structural and physical changes take place in pregnancy such as altered function of urinary tract. The mechanism lying behind low urinary tract function can be described in terms of effects of hormones, compressive dysfunction of uterus and structural changes in pelvic support function. ${ }^{1}$ Urinary incontinence is a functional pelvic floor disorder which affects the wellbeing of all age's women. ${ }^{2}$ Urinary incontinence frequency is increased by pregnancy but the cause of this incontinence is still unknown. The prevalence of incontinence differs greatly. ${ }^{3}$ The prevalence of urinary incontinence in developed countries is $27.6 \%{ }^{4}$ and in 
developing countries is $28.7 \% .^{5}$ No local generalized prevalence for urinary incontinence is found. Associated factors of incontinence during pregnancy are: age, body mass index (BMI), heavy physical activity, cigarette smoking, vaginal delivery and multiple pregnancies. $^{6}$

The International Continence Society (ICS) defines incontinence a condition as unconscious leakage of urine leads to social or hygienic problem. In epidemiological studies urinary incontinence means increase number of urine loss related with uncontrolled urine loss. ${ }^{7}$ There are three main categories of Urinary incontinence: Stress urinary incontinence: Loss of urine with coughing, straining, laughing, physical activity or exercise. Urge urinary incontinence: Loss of urine before reaching the toilet. Mixed incontinence: Combination of both stress and urge urinary incontinence. ${ }^{3}$

There is massive public burden in medical, economic and psychosocial terms and first priority of primary prevention of urine incontinence is to determine affected women. ${ }^{8}$ Vaginal births are major risk factors of incontinences. Instrumental deliveries (vacuum and forceps) can enhance risksparticularly in association with other surgical procedures like episiotomy. But cesarean section decreases the risk of urinary incontinence in comparison with spontaneous and instrumental vaginal deliveries. ${ }^{9}$ The main influence of hormones of pregnancy is to affect the connective tissues. In the period of pregnancy relaxin hormone is produced from placenta, deciduas and ovaries being highest level occur in second trimester results in decrease tensile strength of connective tissues. There are effects of incontinence on quality of life and outside activities. ${ }^{2}$

The aim of this study was to know the frequency of Urinary Incontinence in females with two to three pregnancies.

\section{Patients and Methods}

The study design used was a cross-sectional survey. It was conducted at Lady Aitchson Hospital and Lady Willington Hospital Lahore Pakistan. The study was completed within six months after the approval of synopsis from Ethical Review Committee September 2015 to February 2016.A total of 711 pregnant multigravida participated in the survey among which 5 were excluded from the study on the basis of exclusion criteria that they were diabetic. It was collected through non-probability convenient sampling technique. The sample selection criteria were: Pregnant females from second trimester, age between 25 - 45 years and the exclusion criteria: Females complaining urinary tract infections, females with incontinence before pregnancy related with other disorders e.g. renal diseases, Parkinson's disease and multiple sclerosis, females with hereditary diabetes as females with hereditary diabetes were excluded from the study due to the incontinence caused by the diabetes. In this research we are finding the incontinence purely caused by the anatomical and physiological changes in the women during pregnancy. According to the research, the offspring of women who had diabetes, on average, were more obese and had higher glucose concentrations, ${ }^{10}$ gestational diabetes and gestational hypertension.

An informed consent was taken from each study participants. This survey was done on the multigravida females coming to the hospitals for knowing the prevalence of urinary incontinence from second trimester up to delivery. Females were selected on the basis of inclusion criteria and their convenience. Every woman included was first explained with the significance of this study. Those who were not interested were excluded from the study. They were then asked with the questions in the performa related to urinary incontinence.

Data were analyzed through SPSS (statistical package for social sciences) version 21. All qualitative variables were presented in the form of frequency tables and percentages, bar charts, pie charts. P-value $\leq 0.05$ was taken as significant.

\section{Results}

In this study, $51.1 \%$ females complained of urinary incontinence and $48.8 \%$ with no urinary incontinence during their pregnancy as shown in Table 1. Out of $51.1 \%$ of females suffering from urinary incontinence, $45.5 \%$ were calculated to be suffering from urge incontinence that is they lose urine when they are on their way to toilet. And $38.3 \%$ were suffering from stress incontinence, on an average $41.1 \%$ were suffering from mixed incontinence that is they lose their urine while sneezing, coughing and on their way to toilet. According to the study, $73.6 \%$ of the pregnant multigravida had to get up at night to empty their bladder according to them which disturbed their sleep and affects quality of life.

Out of 363 pregnant females complaining urinary incontinence 183 complaint of beginning of their incontinence in second trimester while 180 in third 
trimester which shows that the incontinence begins as soon as the pregnant female enters in her second trimester due to the increasing weight of the gravid uterus. $50.4 \%$ females complained that their incontinence begins in second trimester and $49.5 \%$ in third trimester as shown in Table 2.

$38.3 \%$ females' complaint of stress urinary leakage during sneezing and coughing according to Table 3 . Table 4 showed that $73.6 \%$ pregnant females have to get up at night to empty their bladders which disturbed their sleep hence affecting the quality of life.

Our analysis showed that the average weight of the baby delivered normally was $3.00 \mathrm{kgs}$.

\section{Discussion}

The results of this study showed that urinary incontinence in pregnant multigravida starts early during their second trimester. Pregnancy beyond $13^{\text {th }}-15^{\text {th }}$ weeks is highly prevalent for urinary incontinence in multigravida. The increase of incontinence in pregnancy was mostly due to high rate of prevalence of urge and mixed urinary incontinence. The multiparous pregnant women had increased prevalence of frequency, nocturia and urgency. Women included in this study were mostly from lower socio economic status.

The results of this study showed that $51.1 \%$ suffered from urinary incontinence and $48.8 \%$ complained of no urinary incontinence during their pregnancy. Incontinence detrimental effects occur at the percentage of $54.3 \%$ of pregnant women in four main areas: travel, physical activity, social interactions and emotional events. ${ }^{11}$ The relative percentages of incontinence were stress incontinence $45.5 \%$, urge incontinence $27.3 \%$ and mixed incontinence $22.9 \%{ }^{8}$

Regarding stress urinary incontinence prevention adequate knowledge given to women and assessment on physical, psychosocial and social domains were reported important treatment strategy. ${ }^{12}$ An evidence
Table 1: Do you have complaint of urinary leakage?

\begin{tabular}{|l|c|r|r|c|}
\hline & Frequency & Percent & $\begin{array}{l}\text { Valid } \\
\text { Percent }\end{array}$ & $\begin{array}{l}\text { Cumulative } \\
\text { Percent }\end{array}$ \\
\hline Yes & 363 & 51.1 & 51.1 & 51.1 \\
\hline No & 343 & 48.8 & 48.8 & 48.8 \\
\hline Total & 706 & 100.0 & 100.0 & \\
\hline
\end{tabular}

Table 2: In Which Trimester Your Episode of Incontinence Begins?

\begin{tabular}{|l|c|c|c|c|}
\hline & Frequency & Percent & $\begin{array}{c}\text { Valid } \\
\text { Percent }\end{array}$ & $\begin{array}{c}\text { Cumulative } \\
\text { Percent }\end{array}$ \\
\hline 2nd trimester & 183 & 26.1 & 50.4 & 50.4 \\
\hline 3rd trimester & 180 & 25.3 & 49.5 & 49.5 \\
\hline Total & 363 & 51.4 & 100.0 & \\
\hline Missing & 343 & 48.6 & & \\
\hline Total & 706 & 100.0 & & \\
\hline
\end{tabular}

Table 3: With Sneeze and Cough Urine Loss.

\begin{tabular}{|l|c|c|c|c|}
\hline & Frequency & Percent & $\begin{array}{c}\text { Valid } \\
\text { Percent }\end{array}$ & $\begin{array}{c}\text { Cumulative } \\
\text { Percent }\end{array}$ \\
\hline Yes & 271 & 38.3 & 38.3 & 38.3 \\
\hline No & 355 & 50.2 & 50.2 & 50.2 \\
\hline Sometimes & 80 & 11.3 & 11.3 & 100.0 \\
\hline Total & 706 & 100.0 & 100.0 & \\
\hline
\end{tabular}

Table 4: Do You Ever Have to Get up at Night to Empty Your Bladder?

\begin{tabular}{|l|c|c|c|c|}
\hline & Frequency & Percent & $\begin{array}{c}\text { Valid } \\
\text { Percent }\end{array}$ & $\begin{array}{c}\text { Cumulative } \\
\text { Percent }\end{array}$ \\
\hline Yes & 520 & 73.6 & 73.6 & 73.6 \\
\hline No & 184 & 26.0 & 26.0 & 26.0 \\
\hline Sometimes & 2 & .3 & .3 & 100.0 \\
\hline Total & 706 & 100.0 & 100.0 & \\
\hline
\end{tabular}

demonstrated that during first trimester of pregnancy multiparous women having stress urinary incontinence had levator ani muscle weakness using MRI. ${ }^{1}$ Recent reports from developed countries indicate that the incidence of multiple births has increased during the 
past 20 years thus increasing the urinary incontinence among multigravida by $65.1 \% .^{13}$

One study stated that higher parity and vaginal delivery are associated risk factors of increased urinary incontinence. $^{14,15}$ More number of vaginal deliveries had a certain effect on urinary incontinence in a pregnant multigravida. In this study, on an average female with $3.00 \mathrm{~kg}$ weight of her child delivered through vagina suffered from urinary incontinence. Bad personal habits and poor hygiene were the major contributors of urinary incontinence in pregnant females. Illnesses like constipation, obesity and hepatitis also had an effect that lead to urinary incontinence in pregnant females.

In two or three times pregnant females, relaxation of pelvic floor muscles causing this problem. Once the prevalence of urinary incontinence in a multigravida female is known we can minimize this complication up to some extent by guiding the female with pelvic floor strengthening exercises. The research on the urinary incontinence in the world has been done on a large scale but in Pakistan no research work has been done regarding urinary incontinence in a multigravida female. This study targeted the population of Pakistan which is totally unaware of the effects of urinary incontinence and hygiene related problems.

There was limitation to the population that was receiving health care facilities free of charge in tertiary health care system. Thus, the findings of this study cannot be generalized to the whole country. Pregnancy and urinary incontinence have a deep relation with each other but in multigravida it is found to be more. Proper guidance and awareness among them is necessary as it will be beneficial for them. Preventive measures and awareness about pelvic muscle strengthening especially during and after pregnancy would be beneficial in overcoming the increased prevalence. Further research on a larger scale is recommended.

\section{Conclusion}

Urinary incontinence is more in multiparous especially in second trimester of pregnancy.

\section{References}

1. Lin $\mathrm{KL}$, Shen $\mathrm{CJ}$, Wu MP, Long $\mathrm{CY}$, Wu CH, Wang CL. Comparison of low urinary tract symptoms during pregnancy between primiparous and multiparous women. BioMed research international, 2014.

2. MacLennan AH, Taylor AW, Wilson DH, Wilson D. The prevalence of pelvic floor disorders and their relationship to gender, age, parity and mode of delivery.
BJOG: An International Journal of Obstetrics \& Gynaecology, 2000; 107 (12): 1460-70.

3. Hannestad YS, Rortveit G, Sandvik H, Hunskaar S. A community-based epidemiological survey of female urinary incontinence: The Norwegian EPINCONT Study. Journal of clinical epidemiology, 2000; 53 (11): 1150-7.

4. Minassian VA, Drutz HP, Al-Badr A. Urinary incontinence as a worldwide problem. International Journal of Gynecology \& Obstetrics, 2003; 82 (3): 327-38.

5. Walker GJ, Gunasekera P. Pelvic organ prolapse and incontinence in developing countries: review of prevalence and risk factors. International Urogynecology Journal, 2011; 22 (2): 127-35.

6. Solans-Domènech $M$, Sánchez $E$, Espuña-Pons $M$, Group PFR. Urinary and anal incontinence during pregnancy and postpartum: incidence, severity, and risk factors. Obstetrics \& Gynecology, 2010; 115 (3) :618-28.

7. Hunskaar S, Burgio K, Diokno A, Herzog AR, Hjälmås K, Lapitan MC. Epidemiology and natural history of urinary incontinence in women. Urology, 2003; 62 (4): 16-23.

8. Goldberg R, Kwon C, Gandhi S, Atkuru L, Sand P. Urinary incontinence after multiple gestation and delivery: impact on quality of life. International Urogynecology Journal, 2005; 16 (5): 334-6.

9. Farrell SA, Allen VM, Baskett TF. Parturition and urinary incontinence in primiparas. Obstetrics \& Gynecology, 2001; 97 (3): 350-6.

10. Pettitt DJ, Nelson RG, Saad MF, Bennett PH, Knowler WC. Diabetes and obesity in the offspring of Pima Indian women with diabetes during pregnancy. Diabetes Care, 1993; 16 (1): 310-4.

11. Sangsawang B, Sangsawang N. Stress urinary incontinence in pregnant women: a review of prevalence, pathophysiology, and treatment. International Urogynecology Journal, 2013; 24 (6): 901-12.

12. Perera J, Kirthinanda DS, Wijeratne S, Wickramarachchi TK. Descriptive cross sectional study on prevalence, perceptions, predisposing factors and health seeking behaviour of women with stress urinary incontinence. BMC women's health, 2014; 14 (1): 1.

13. Eason E, Labrecque M, Marcoux S, Mondor M. Effects of carrying a pregnancy and of method of delivery on urinary incontinence: a prospective cohort study. BMC pregnancy and childbirth, 2004; 4 (1): 1.

14. Glazener CMA, Herbison G, MacArthur C, Lancashire R, McGee M, Grant AM, et al. New postnatal urinary incontinence: obstetric and other risk factors in primiparae. BJOG: An International Journal of Obstetrics \& Gynaecology, 2006; 113 (2): 208-17.

15. MacArthur C, Glazener C, Wilson PD, Lancashire RJ, Herbison GP, Grant AM. Persistent urinary incontinence and delivery mode history: a six-year longitudinal study. BJOG: An International Journal of Obstetrics \& Gynaecology, 2006; 113 (2): 218-24. 